\title{
How financial Crisis Effect the Dynamics of Exchange rate? Revisit the Portfolio Balance Model in the presence of financial Crisis
}

Hafsa Hina ( $\sim$ hafsahina@pide.org.pk)

Pakistan Institute of Development Economics https://orcid.org/0000-0001-9931-1957

Muhammad Najeeb

Hamdard University - Islamabad Campus

\section{Research}

Keywords: Financial crisis, Portfolio balance model, Exchange rate dynamics

Posted Date: February 15th, 2022

DOI: https://doi.org/10.21203/rs.3.rs-1073005/v1

License: (c) (i) This work is licensed under a Creative Commons Attribution 4.0 International License.

Read Full License 


\title{
How financial Crisis Effect the Dynamics of Exchange rate? \\ Revisit the Portfolio Balance Model in the presence of financial Crisis \\ Hafsa Hina $^{1}$ and Muhammad Najeeb ${ }^{2}$
}

\begin{abstract}
In this paper the influence of financial crisis on dynamics of exchange rate is captured by modifying the Portfolio balance model of Branson et al. (1985). This modification is based on the assumption that financial crisis originates in a foreign country and transmits to a small country via financial markets. It alters the preferred portfolio composition by influencing the need for domestic and international bonds. After establishing the basic conceptual framework, the effect of financial crisis on exchange rate is investigated in two scenarios. First case has considered a small domestic economy with no internal crisis. The emergence of a financial crisis in this case causes the currency to appreciate by rising demand for domestic financial assets while decreasing demand for international financial assets. Case two has considered the opposite economy which is experiencing a serious internal crisis at the time of external financial crisis. Hence, financial crisis originated in the foreign country affects the small country's growth by reducing its ability to attract the capital funds from abroad. The domestic investor then speculates that financial crisis further worsens the economic growth and weakens the domestic currency which further makes the domestic bond relatively riskier than foreign bond. This motivates them to change the structure of portfolio investment by shifting their money out of domestic bonds to foreign bonds and consequently it depreciates the domestic currency. Finally, the empirical validity of second case is confirmed for Pakistan.
\end{abstract}

Keywords: Financial crisis; Portfolio balance model; Exchange rate dynamics.

JEL Classification: B26, C58, D51, E4, G1.

${ }^{1}$ Hafsa Hina <hafsahina@ pide.org.pk, Office Telephone \# 092519248047> is Assistant Professor at, Pakistan Institute of Development Economics, Islamabad, Pakistan. Corresponding Author. ${ }^{2}$ Muhammad Najeeb < m.najeeb@hamdard.edu.pk> is Lecturer at Humdard University Islamabad> 


\section{Introduction}

Following the 2007-08 global financial crisis, the emphasis of economic theory is intensively to provide an alternative solution to keep the economy on track in achieving the goals of sustainable economic system. Economic theories are fail to predict the crisis because crisis are taken as irregular event and therefore haven't consider in the development of economic theories. But it's time to change the perception that crisis especially financial crisis are unpredictable, now they are predictable $^{1}$. The inclusion of financial crisis variable in the existing asset approach ${ }^{2}$ to exchange rate determination will bring the theory into closer contact with reality.

The portfolio balance model (PBM) is a method of determining the exchange rate (ER) based on asset markets. PBM has its origin in the research performed by William Branson (1977, 1979, 1985), Israd (1978) and Kouri (1976), and further modified by Obstfeld (1985), Allen and Kenen (1980), Branson and Henderson (1985) and Cushman (2007).

The supply and demand condition in the financial asset markets decide the exchange rate in the PBM. The essential features of PBM are the presumption of wealth impact of current account surplus/deficit and the imperfect substitutability between national (domestic) and international (foreign) bonds. Both of these features are omitted in monetarist models of ER determination.

The current account (CA) is heavily inclined by the rate of exchange among currencies. Countries which have the benefit of current account surplus either increase its accumulation of foreign assets or may decrease its foreign debt and affect the level of domestic wealth and this ultimately affects the ER. As a result, in addition to monetary fundamentals, domestic and foreign reserves have a huge influence on the ER through the CA. PBM provides the short run analysis of ER and national interest rate determination from the asset market equilibrium condition. It is a complex model of ER adjustment that consist of asset markets, the CA, price level, and the rate of asset accumulation as terms of reference (Pilbeam, 1998).

Keynesian and Monetarist models of exchange rate typically analyze the impacts of standard macro shock of fiscal policy and monetary policy on ER. PBM, instead, considers the effect of financial market behavior on short-run ER and interest rate dynamics (Branson, 1985).

The macroeconomic ties between countries are provided by exchange rate through good and asset markets. ER theory delivers the macroeconomic relations among the countries through good and asset markets. Therefore, it can be argued that crisis originates in one country transmits to another country through financial sector and international trade which disturbs the macroeconomic fundamentals of the economy.

The primary goal of this research is to incorporate a financial crisis variable into the portfolio balance model of Branson et al. (1985) and examine its effect on the preferred portfolio structure, equilibrium ER and interest rate, and CA dynamics for small open economies. After the theoretical development the study moves to investigate its empirical validity in case of Pakistan. Because it is small economy and very prone to external shocks.

\footnotetext{
${ }^{1}$ Tjahjawandita et al. (2009) have developed the index of financial crisis by combining stock market, banking and currency crisis. Kaminsky and Reinhart (1999) have calculated the conditional and unconditional probabilities to examine how banking crisis and the currency crisis are linked together. The probabilities indicate that prior information on one crisis, which occurred within past 24 months, helps to predict the occurrence of another crisis.

${ }^{2}$ The asset approach to models of exchange rate has emerged during 1970 's, with the liberalization of global financial market.
} 
Following the introduction, the rest of the paper is organized into two sections. Section 2 describes the theoretical development of the modified PBM and empirical analysis is presented in Section 3.

\section{Theoretical Development of Modified Portfolio Balance Model}

Let's take the assumption of modified portfolio balance model (MPBM). It has the same properties as in the original Branson's PBM. The assumptions of MPBM are listed below

1. First, assume two countries, small domestic country and large foreign country.

2. Second, financial crisis originates in foreign country and small country takes it as exogenous shock.

3. Third, total wealth of a country is consisting of monetary wealth (domestic money stock and it is not traded internationally) and non-monetary wealth (non-traded domestic bond and traded foreign bonds).

4. Fourth, demand for domestic and foreign bond is influenced by financial crisis and money market is independent of financial crisis.

5. Fifth, national and international assets are gross substitutes and offers different level of expected returns, depending upon the risk associated with each asset. Risk averse investor, generally, requires higher level of expected return on high-risk bond as compared to lowrisk bond. The risk premium is the additional expected return on a risky bond. Therefore, UIP no longer holds in PBM i.e.

$$
i-i^{*}=\Delta s^{e}+R p \text { (hereafter } x=\Delta s^{e} \text { and } R p \text { is the risk premium) }
$$

6. Six, domestic output and prices are fixed and only respond to change in economic policy. The stock of domestic currency, national bonds, international bonds, and level of foreign interest rates are decided exogenously, while the asset market equilibrium condition determines the level domestic interest rate $(i)$ and ER.

\subsection{Mechanism of Modified PBM}

The PBM is established on the subsequent asset system

$$
\begin{array}{lc}
M=m\left(Y, i, i^{*}, x\right) W & m_{Y}>0, m_{i}<0, m_{i^{*}}<0, m_{x}<0 \quad \text { (Money market) } \\
B=b\left(Y, i, i^{*}, x, F C\right) W & b_{Y}>0, b_{i}>0, b_{i^{*}}<0, b_{x}<0, b_{F C}{ }^{3} \quad \text { (Bond Market) } \\
s B^{*}=b^{*}\left(Y, i, i^{*}, x, F C\right) W & b_{Y}^{*}<0, b_{i}^{*}<0, b_{i^{*}}^{*}>0, b^{*}{ }_{x}>0, b^{*}{ }_{F C} 2 \\
W=M+B+s B^{*} & \text { (Foreign bonds held by domestic residents) } \\
\text { (Wealth constraint) }
\end{array}
$$

Where $M$ :Domestic nominal money supply, $Y$ :real Domestic income (real), $i$ : Domestic nominal interest rate, $i^{*}$ : Foreign nominal interest rate, $x$ : Expected rate of depreciation $x=s^{e}-s / s$ or $x=\frac{s^{e}}{s}-1, s:$ Exchange rate, $s^{e}$ : Expected exchange rate, $W$ :Total nominal

\footnotetext{
${ }^{3}$ The latter section will discuss the signs of $b_{F C}$ and $b_{F C}^{*}$.
} 
domestic wealth $\quad, B$ : Domestic/national bond supply-nominal, $B^{*}:$ Foreign/international bonds held by domestic residents- nominal, $b^{*}$ : Demand for foreign bonds (real), $b$ : Demand for domestic bonds (real), $m$ : Real money demand, $F C$ : Financial Crisis Variable, and $m W, b W, b^{*} W$ is the proportion of wealth in domestic money, domestic bond and foreign bond. Implies the wealth constraint

$$
W=m W+b W+b^{*} W \quad \text { or } \quad 1=m+b+b^{*}
$$

Balance sheet identity (1d) is associated with the assumptions that is money demand, domestic and foreign bonds are unit elastic with respect to wealth that is any increase in wealth is held in these three assets : $m_{W}+b_{W}+b_{W}^{*}=1$. Further the sum of impact of change in any rate of return or expected rate of return on all these assets are zero i.e.

$$
\begin{aligned}
& m_{i}+b_{i}+b_{i}^{*}=0 \\
& m_{i^{*}}+b_{i^{*}}+b_{i^{*}}^{*}=0 \\
& m_{x}+b_{x}+b_{x}^{*}=0
\end{aligned}
$$

Each asset is presumed to have a positive relationship with its own rate of return and a negatively related to the rate of return of other assets (i.e. $b_{i}>b_{i^{*}}$ and $b_{i^{*}}{ }^{*}>b_{i}^{*}$, the effect of the own rate of return is bigger than the effect of the cross rate of return in absolute terms). It is also supposed that national and international bonds are gross substitutes (i.e. $b_{i}>b_{i}^{*}$ and $b^{*}{ }^{*}{ }^{*}>b_{i^{*}}$, demand for national bonds is more (less) prone to the domestic (foreign) interest rate than demand for international bonds. This can be inferred from equation 3(4)).

To consider the relative effect of policy variables and the FC on the exchange rate, a comparative static analysis on the asset system is performed. (See Appendix)

Effects of $M, B, B^{*}, i^{*}, s^{e}, Y$ on exchange are as follows

The mechanism through which money supply depreciates the national currency is defined as with the increase in money supply lead to decrease the $i$ and rise the transitive demand for domestic money. As of the lower $i$, investors would demand more foreign bonds. To satisfy the wealth constraint, investors decrease the demand for domestic bonds which would depreciate the national currency.

$$
\frac{d s}{d B}=\frac{-m_{i} b^{*}+m b_{i}^{*}}{-m_{i}\left(B^{*}\left(1-b^{*}\right)-W b_{s}^{*}\right)-b_{i}^{*}\left(W m_{s}+m B^{*}\right)} ?
$$

Depending on the substitution and wealth effect, an increase in the supply of national bonds may either lower or raise the exchange rate. If the wealth effect outweighs the substitution effect, for example, domestic currency would depreciate. This is due to a raise in the supply of national bonds would equally increase the national wealth. If investor redefines his portfolio composition by demanding more international bonds than national bonds, this would depreciate the domestic currency. Contrastingly, if the wealth effect is replaced by the substitution effect (interest rate effect), the national currency would appreciate. This is defined, as a rise in the supply of national bond results into reducing its price and increasing the $i$. Higher interest rate decreases the demand 
for money and encourages investors to rebalance their portfolios by shifting their investments from international to national bonds, causing the national currency to appreciate (Moosa and Bhatti, 2009).

$$
\frac{d s}{d B^{*}}=\frac{m_{i}\left(1-b^{*}\right) S+b_{i}^{*} m S}{-m_{i}\left(B^{*}\left(1-b^{*}\right)-W b_{s}^{*}\right)-b_{i}^{*}\left(W m_{s}+m B^{*}\right)}<0
$$

The appreciating impact of increased foreign bond supply over domestic currency is explained by equation (11). Given the supposition of a static foreign interest rate and ER, a rise in the supply of international bonds needs a drop in the $i$. The fall in $i$ increases the demand for domestic money and appreciates the national currency (Pilbeam, 1998).

$$
\frac{d s}{d i^{*}}=\frac{-W m_{i} b^{*}{ }^{*}+W b_{i}^{*} m_{i^{*}}}{-m_{i}\left(B^{*}\left(1-b^{*}\right)-W b_{s}^{*}\right)-b_{i}^{*}\left(W m_{s}+m B^{*}\right)}>0
$$

In Equation (12), increase in the foreign interest rate will initially increase demand for international bonds, while the proportion of wealth held in national currency will decrease $\left(m_{i^{*}}<0\right)$. Further, the decrease in domestic money demand at given money supply requires a fall in $i$. The demand for domestic money and international bonds would increase as the $i$ falls. To maintain the wealth constraint, investor reduces the holding of domestic bonds, as this would depreciate the domestic currency.

$$
\frac{d s}{d s^{e}}=\frac{-W m_{i} b_{s^{e}}^{*}+W b_{i}^{*} m_{s^{e}}}{-m_{i}\left(B^{*}\left(1-b^{*}\right)-W b_{s}^{*}\right)-b_{i}^{*}\left(W m_{s}+m B^{*}\right)}>0
$$

The result of change in expected ER is explained in equation (13). It reveals that if expected exchange rate depreciates then it would reduce the demand for domestic money and increase the demand for international bonds. This action would further decrease the $i$. The demand for domestic money and international bonds would increase as the domestic interest rate falls. To maintain the wealth constraint, investor reduces the holding of domestic bonds, as this would depreciate the domestic currency.

$$
\frac{d s}{d Y}=\frac{-W m_{i} b^{*}+W b_{i}^{*} m_{Y}}{-m_{i}\left(B^{*}\left(1-b^{*}\right)-W b_{s}^{*}\right)-b_{i}^{*}\left(W m_{s}+m B^{*}\right)}<0
$$

Increased domestic income causes the national currency to appreciate in the asset market. That is, as domestic real income rises, so does demand for domestic currency, while demand for international assets falls. The $i$ rises in response to a rise in domestic demand at a given money supply. The demand for international bonds and domestic money decreases as interest rates rise. To preserve the wealth constraint, higher interest rate invites the investors to invest in domestic bonds and this would lead to appreciate the domestic currency.

The influence of financial crisis on short run equilibrium ER is examined under the following section. 


\subsection{Impact of Financial Crisis on Exchange rate}

To examine the role of FC on ER, consider two cases.

Case 1: $b_{F C}^{*}<0$ and $b_{F C}>0$

Suppose the economy is not experiencing any type of internal crisis and takes the financial crisis as an external shock. Therefore, financial crisis originated in the foreign alter the asset preferences, by making the foreign asset riskier as compare to domestic bond. This will induce the domestic investor to change the structure of portfolio investment by shifting his money out of foreign bond to domestic bond. Thus, In this case $b_{F C}^{*}<0$ and $b_{F C}>0$. The influence of financial crisis on ER is

$$
\frac{d s}{d F C}=\frac{-W m_{i} b_{F C}{ }^{*}}{-m_{i}\left(B^{*}\left(1-b^{*}\right)-W b_{s}^{*}\right)-b_{i}^{*}\left(W m_{s}+m B^{*}\right)}<0
$$

Given the above conditions, the negative sign of the above term means that the national currency will appreciate in the presence of a financial crisis.

This finding can be illustrated with the help of diagram. $M M, B B$ and $B^{*} B^{*}$ schedules (in the Figure 1), represents the domestic money market, national bond market and international bond market schedules. Each schedule depicts various ER and domestic interest rate combinations in which the supply of each asset is equal its demand given the exogenous variables remain constant.

The slope of $M M, B B, B^{*} B^{*}$ schedules can be derived from equations (1a) - (1c) by using $1 \mathrm{~d}$ in each equation and set the change in exogenous variables to zero $\left(d M=0, d B=0, d B^{*}=0, d \bar{s}=0, d Y=0, d i^{*}=0, d F C=0\right)$.

$$
\text { Slope of MM } \frac{d s}{d i}=\frac{-W m_{i}}{m B^{*}+W m_{s}}>0
$$

Since, $m_{i}<0$ and $m_{s}>0$.

The MM schedule has a positive slope and demonstrates domestic money market equilibrium. The argument for an upward sloping MM is that a depreciation in the ER increases the income of national investors (international assets are worth more after the depreciation). A rise in wealth contributes to a surge in money demand. However, since the money supply is fixed, a rise in the interest rate is the only way to meet the increased money demand.

$$
\text { Slope of BB } \frac{d s}{d i}=\frac{-W b_{i}}{b B^{*}+W b_{s}}<0
$$

Since, $b_{i}>0$ and $b_{s}>0$.

The BB schedule is sloped downward. It states that a weakening of the local currency increases the wealth of national investors and increases demand for national bonds. However, given the current stock of national bonds, the amplified demand for national bonds can only be balance by a decrease in interest rates. 


$$
\text { Slope of } \mathrm{B}^{*} \mathrm{~B}^{*} \frac{d s}{d i}=\frac{W b^{*}{ }_{i}}{B^{*}\left(1-b^{*}\right)-W b_{s}{ }_{s}}<0
$$

Since, $b^{*}{ }_{i}<0$ and $b^{*}{ }_{s}<0$.

Finally, the $\mathrm{B} * \mathrm{~B}$ schedule representing market equilibrium for international bonds is also sloped downward. The explanation for this is that a weakening of the ER increases demand for national bonds, causing investors to sell capital and international bonds in order to purchase national bonds. A rise in the interest rate, contrastingly, makes national bonds more appealing than international bonds, causing investors to buy national bonds and sell international bonds, causing the national currency to appreciate.

Since $b_{i}>b_{i}^{*}$, the $\mathrm{B} * \mathrm{~B} *$ line is sharper than the $\mathrm{BB}$ line, which is needed in the asset market for balanced portfolio equilibrium. The asset market is in balance, when all three asset markets clear at the required domestic interest rate and ER. That is, all three schedules intersect each other at unique point, as depicted in Figure 1.

\section{Figure 1: Equilibrium of Portfolio Balance Model}

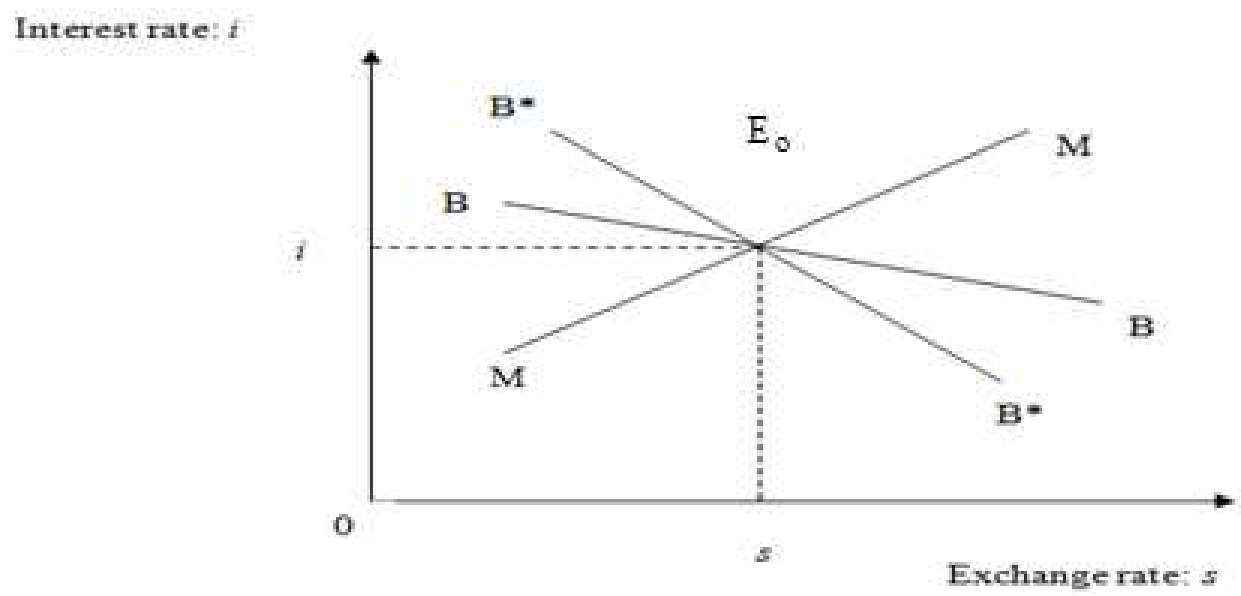

\section{The Effect of Financial Crisis on Short Run Equilibrium ER and Interest Rate}

Initially, in Figure 2, the equilibrium of asset market is at point $E_{0}$, where the schedules of all three asset markets intersect each other. The equilibrium domestic interest rate is $i_{0}$ and ER is $s_{0}$.

The occurrence of financial crisis in foreign country, makes the foreign bond $\left(B^{*}\right)$ riskier relative to domestic bond $(B)$. As a result, domestic investors' demand for international bonds decreased while their demand for national bonds increased.

The increase in the demand for domestic bond moves the $B B$ curve to left ward from $B B_{o}$ to $B B_{1}$ as the higher demand for domestic bond is justified by lowering the price of domestic bond (interest rate $i$ ). The decrease in the demand for foreign bond shifts the $B^{*} B^{*}$ schedule to left ward, from $B * B *_{o}$ to $B * B *_{1} . M M$ schedule is independent of financial crisis. The final equilibrium is at E1, where the new equilibrium domestic interest rate is $i_{1}$ and the ER is $s_{1}$. As a result, a financial crisis 
causes a short-term appreciation of the national currency and a reduction in the domestic interest rate.

Figure 2: The Effect of Financial Crisis under Case 1

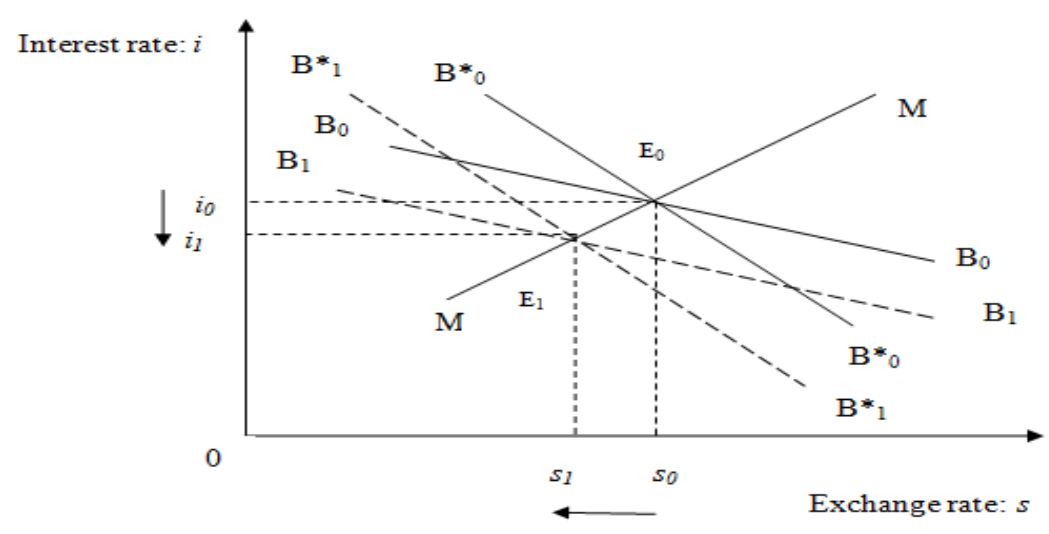

Case 2: $b_{F C}^{*}>0$ and $b_{F C}<0$

In this case it is assumed that domestic economy is experiencing a serious internal crisis such as political instability, weak currency, inflation risk, business risk etc, at the time of financial crisis, and takes the financial crisis as an external shock.

The domestic investor may conceive that financial crisis further worsen the domestic country as it is already facing internal crisis. This will increase the risk to hold domestic bond. In this situation, financial crisis makes domestic bond riskier as compared to foreign bond. This will induce the domestic investor to redefine the portfolio composition by shifting his money out of domestic bond to foreign bond. Thus, in this case $b_{F C}^{*}>0$ and $b_{F C}<0$. The impact of financial crisis on exchange rate is

$$
\frac{d s}{d F C}=\frac{-W m_{i} b_{F C}{ }^{*}}{-m_{i}\left(B^{*}\left(1-b^{*}\right)-W b_{s}^{*}\right)-b_{i}^{*}\left(W m_{s}+m B^{*}\right)}>0
$$

Positive sign of the above expression indicates that financial crisis will result into the depreciation of domestic currency, given the above conditions. This finding is more elaborated with the help of Figure 3.

Initially, in Figure 3, the equilibrium of asset market is at point $E_{0}$, where the schedules of all three asset markets intersect each other. The equilibrium domestic interest rate is $i_{0}$ and ER is $s_{0}$.

Under case 2, occurrence of financial crisis in foreign country, makes the domestic bond $(B)$ riskier as compare to foreign bond $\left(B^{*}\right)$. As a result, domestic investors increased international bond demand while decreasing domestic bond demand.

The decrease in the demand for domestic bond is justified by raising the price of domestic bond (interest rate $i$ ). This shifts the $B B$ curve to rightward from $B B_{o}$ to $B B_{1}$. The rise in the demand for foreign bond moves the $B * B *$ line leftward, from $B * B^{*}{ }_{o}$ to $B * *^{*}{ }_{1}$. MM schedule is independent of financial crisis. The new equilibrium is at point $E_{1}$ where the new equilibrium domestic interest 
rate is at $i_{1}$ and the ER is $s_{1}$. Due to the occurrence of financial crisis, the national currency depreciates and the domestic interest rate rises in the short run.

Figure 3: The Effect of a Financial Crisis under Case 2

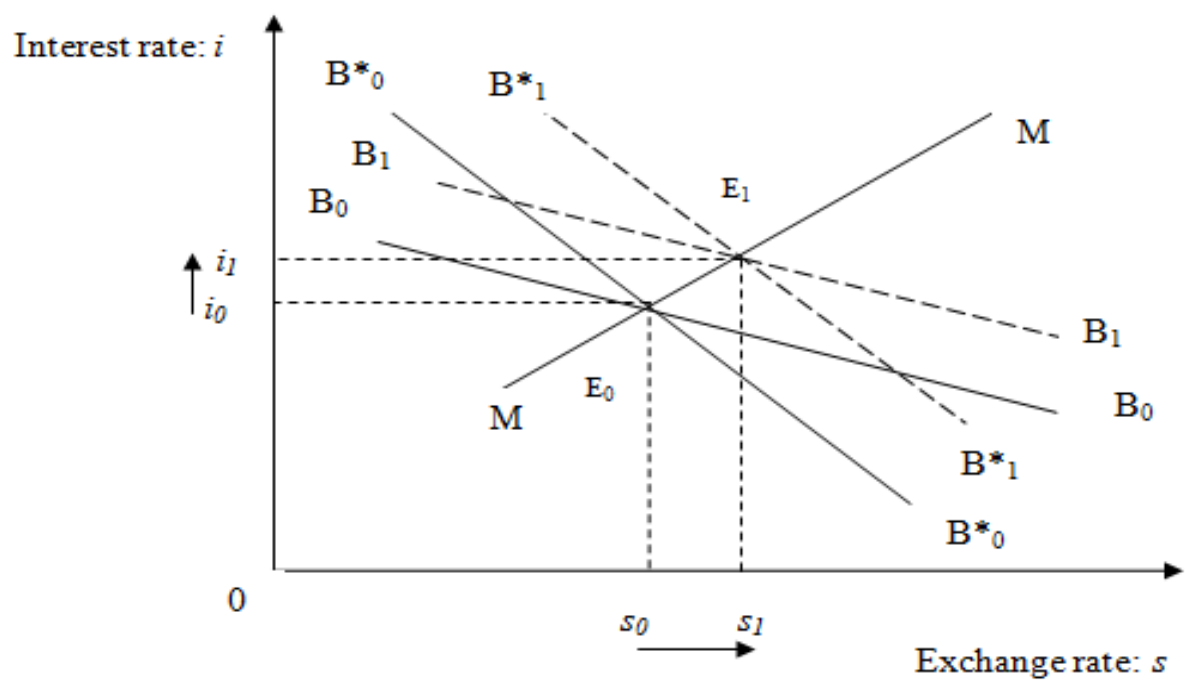

Short run fundamental exchange rate determination equation under MPBM, with expected signs is given by:

$$
s=f\left(\stackrel{+}{M}, \stackrel{?}{B}, \bar{B}^{*}, i^{*}, s^{e}, \bar{Y}, \stackrel{?}{F C}\right)
$$

\subsection{The Dynamics of Financial Crisis}

To differentiate between the short run and long run equilibrium in the model, we now describe the dynamics of financial crises. Through a CA surplus or deficit, foreign asset holdings may rise or fall over time. As a result, the CA surplus suggests the accumulation of foreign bonds, which can be explained as the partial derivative of foreign bond holdings over time, i.e.,

$$
C A=\frac{\partial B^{*}}{\partial t}=B^{*}=T\left(Y, Y^{*}, \frac{s P^{*}}{P}\right)+i^{*} B^{*}
$$

where $T$ is the trade balance (with $T_{Y}<0, T_{Y^{*}}>0, T_{\frac{s P^{*}}{P}}>0$ ) and $i^{*} B^{*}$ is the interest rate receipt from net holdings of foreign assets. A current account surplus influences equity markets by the accumulation of foreign bonds, even though the trade balance remains unchanged, if $C A>0$, then $B^{*}>0$ if $T=0$. If the growth of foreign assets lasts, net earnings from foreign assets $\left(i^{*} B^{*}\right)$ also increases. Widening the surplus and causing $B^{*}$ to rise even further.

In long run $\mathrm{CA}$ is in balance and the exchange rate has remained unchanged. It implies that the country is neither decreasing nor increasing its foreign holding and the exchange rate is at a stable level.

\subsubsection{The Dynamics of Financial Crisis under Case 1}


Figure 4.4 explains the dynamics of ER and CA following the effect of financial crisis under case 1 , which causes an appreciation of ER. Let suppose financial crisis occur at time $t_{1}$, it will increase the demand for national bond and decreases the demand for international bond. As a result, the local currency appreciates from $s_{1}$ to $s_{2}$, there has been a real exchange rate appreciation due to fixed prices. It deteriorates country international competitiveness and causes trade deficit and moves current account into deficit. To balance its current account, the nation begins to sell more international bonds. As a result, the investor's portfolio would have a higher proportion of national bonds. To mitigate this danger, investors could begin selling domestic bonds, causing in a depreciation of the national currency. As a result, the country's competitive advantage will increase, and the CA deficit will shrink. When the ER has depreciated sufficient to bring the CA back into balance, the dynamics come to an end. The key feature is that the long-term ER is higher than the initial rate $s$. This is because a CA deficit causes an erosion of foreign bonds and a reduction in the payment of interest rate receipts from the keeping of international bonds. As a result, the ER would depreciate in the long run equilibrium, resulting in an increase in the trade balance to offset the decline in the service account and ensure that the CA is returned to balance in the long run.

Figure 4: The Dynamics of Financial Crisis in PBM under Case 1

(a) The Exchange Rate

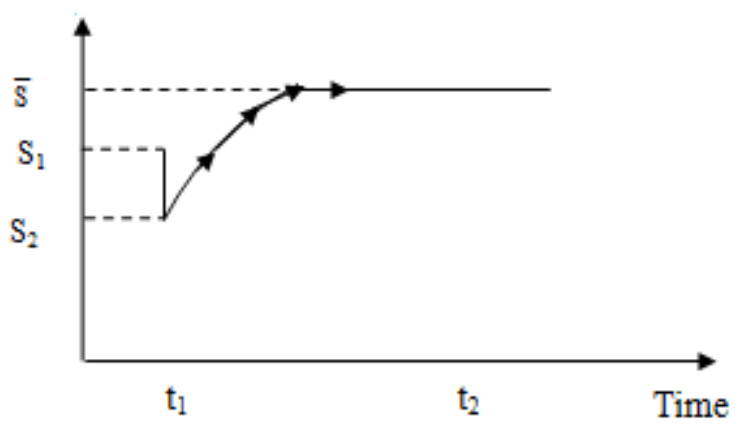

(b) The Current Account

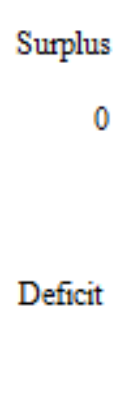

\subsubsection{The Dynamics of Financial Crisis under Case 2}

Figure 5 explains the dynamics of the ER and CA as a result of the FC in Case 2, which causes the ER to depreciate. The occurrence of financial crisis occur at time $t_{1}$, decrease the demand for national bond and increase the demand for international bond. Consequently, the local currency has depreciated from $s 1$ to $s 2$ due to fixed prices, resulting in a real exchange rate depreciation. It boosts a country's international competitiveness by causing a trade surplus and a positive current account balance. To balance its current account, the nation begins to buy more international bonds. As a result, the proportion of domestic bonds in an investor's portfolio will decrease. To mitigate this danger, investors should begin purchasing domestic bonds, which will effect in a firming of the local currency. As a result, the country's competitive advantage would deteriorate, raising the CA deficit. When the ER has appreciated enough to get the CA back into balance, the dynamics come to an end. The key feature is that the long run ER is lower than the initial rate $s 1$. This is due to CA surplus after an operation results in the addition of international bonds and a rise in the payment of interest rate receipt from the stock of international bonds on the current account's service part. Therefore, in the long run equilibrium, the ER must appreciate, resulting in a 
worsening of the trade balance to offset the increase in the service account and ensure that the CA is returned to balance in the long run.

Figure 5: The Dynamics of Financial Crisis in PBM under Case 2
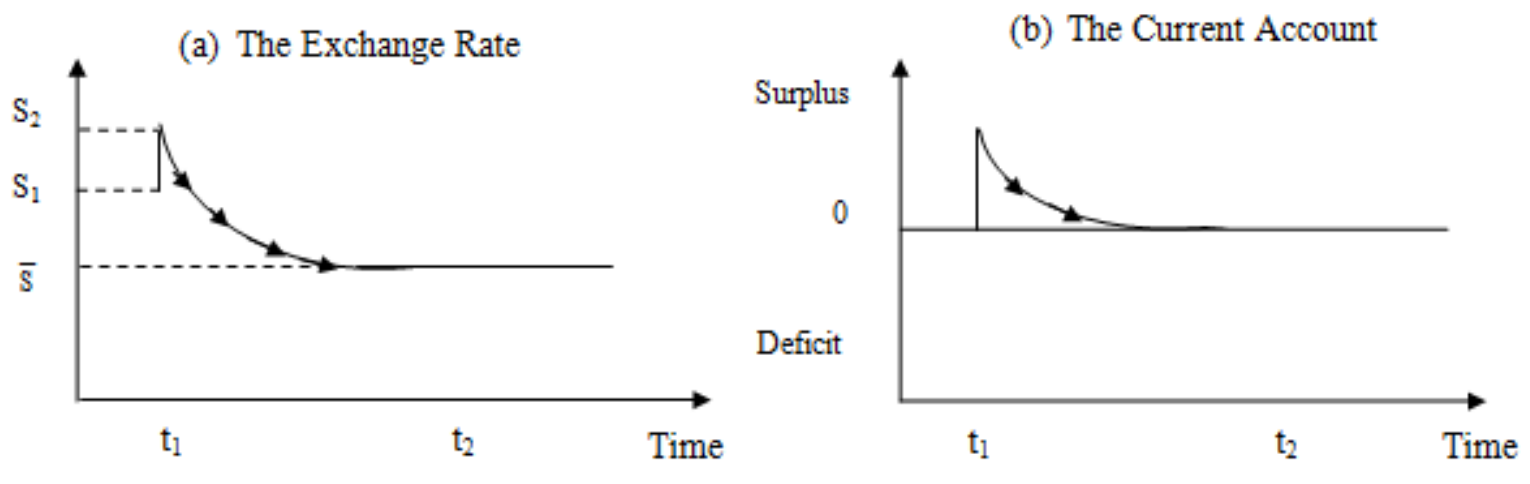

\section{Empirical Analysis of the MPBM}

In this section our aim is to verify the second case of MPBM in case of Pakistan. Pakistan is a small open economy and its economy is very fragile to internal and external crisis due to instable economic conditions [for more details see Hina and Qayyum, 2019]. After its independence, Pakistan has to deal with a variety of ER regimes in order to attain the goals of improving export competitiveness, improving the balance of payments, and accelerating economic development. [for more detail see Hina and Qayyum 2016, Haque and Hina (2020), Hina (2020)].

The MPBM estimates are calculated using the multivariate cointegration technique of Johansen and Juselius (1992). This technique enables us to find the long-run and short-run estimates of the model. Data was collected from 1982: Q1 to 2014: Q2 during the flexible ER era. The information comes from the International Financial Statistics (IFS) and the Monthly Statistical Bulletin of the State Bank of Pakistan (SBP) (various issues) and Treasury International Capital (TIC). The nominal exchange rate is expressed in Pakistan rupee (PKR) units per US dollar unit. Expected exchange rate $\left(s^{e}\right)$ is measured by three-month previous period's forward exchange rate. Broad money M2 is used to calculate the domestic money supply $(m)$. Real gross domestic product (GDP) is used to describe the real output level $(y)$. Deflating nominal GDP on the GDP deflator $(2000=100)$ yields real GDP at a constant base of 2000. In the case of Pakistan, the annual real GDP is quartered using the Kemal and Arby methodology (2004). The federal funds rate is an indicator of interest rate in the United States $(i)$. Pakistan government debt held privately, minus Pakistan government debt held by non-residents, is classified as domestic securities held by domestic residents $(b)$. It is measured by permanent debt and floating debt outstanding. Foreign (US) securities held by Pakistani residents $\left(b^{*}\right)$ are measured as sum of U.S. agency bonds, U.S. corporate bonds, U.S. stocks and U.S. treasury bonds in millions of U.S. dollar held by Pakistan. Tjahjawandita et al. (2009), methodology is adopted to measure the financial crisis index $\left(F C_{t}\right)$. Accordingly, financial crisis index is composite of The description and detail of financial crisis index is available in Hina and Qayyuum (2019).

Except for the interest rate, all variables in MPBM have been converted into logarithmic form. The HEGY (1990) unit root test is used to determine whether a seasonal or non-seasonal unit root exists. Table 1 summarizes the findings. As shown in Table 1, all MPBM variables have zero 
frequency non-seasonal unit roots, and the presence of biannual and annual frequency unit roots are rejected at the 5\% significance level. As a result, the first difference is use to make the series stationary. The results of HEGY (1990) test on the first difference confirm that these variables are first difference stationary.

Table 1: HEGY Test: Seasonal Unit Roots

\begin{tabular}{|c|c|c|c|c|c|c|c|c|}
\hline \multirow[b]{3}{*}{ Variable } & \multirow{2}{*}{\multicolumn{4}{|c|}{ Regressors }} & \multicolumn{3}{|c|}{ Null \& Altemative Hypothesis } & \multirow[b]{3}{*}{$\begin{array}{l}\text { Roots } \\
\text { (Filter) }\end{array}$} \\
\hline & & & & & $\begin{array}{l}\pi_{1}=0 \\
\pi_{1}<0\end{array}$ & $\begin{array}{l}\pi_{2}=0 \\
\pi_{2}<0\end{array}$ & $\begin{array}{l}\pi_{3}=\pi_{4}=0 \\
\pi_{3} \neq \pi_{4} \neq 0\end{array}$ & \\
\hline & Lags & Drift & Trend & $\begin{array}{l}\text { Seasonal } \\
\text { Dummies }\end{array}$ & $t_{z_{i}}$ & $t_{x_{2}}$ & $F_{x_{y}, x_{i}}$ & \\
\hline$s$ & 0 & Yes & No & No & $-0.81^{*}$ & -5.76 & 55.37 & $\begin{array}{c}1 \\
(1-B)\end{array}$ \\
\hline$y$ & 3 & Yes & No & No & $-2.10^{2}$ & -8.81 & 29.61 & $\begin{array}{c}1 \\
(1-B)\end{array}$ \\
\hline$i^{*}$ & 0 & Yes & Yes & Yes & $-3.14^{*}$ & -8.12 & 73.87 & $\begin{array}{c}1 \\
(1-B)\end{array}$ \\
\hline$m$ & 0 & Yes & Yes & Yes & $-2.13^{2}$ & -6.47 & 56.63 & $\begin{array}{c}1 \\
(1-B)\end{array}$ \\
\hline$s^{e}$ & 0 & Yes & No & No & $-0.76^{\circ}$ & -5.91 & 51.35 & $\begin{array}{c}1 \\
(1-B)\end{array}$ \\
\hline$b$ & 0 & Yes & Yes & No & $-2.25^{*}$ & -5.09 & 71.53 & $\begin{array}{c}1 \\
(1-B)\end{array}$ \\
\hline$b^{*}$ & 0 & Yes & Yes & No & $-3.31^{2}$ & -7.11 & 52.41 & $\begin{array}{c}1 \\
(1-B)\end{array}$ \\
\hline$F C$ & 0 & Yes & No & No & $-2.59^{4}$ & -5.89 & 67.23 & $\begin{array}{c}1 \\
(1-B)\end{array}$ \\
\hline \multicolumn{9}{|c|}{ HEGY test on Filtered Series } \\
\hline$(1-B) s$ & 0 & Yes & No & No & -4.86 & -4.79 & 26.77 & $\mathrm{I}(0,0)$ \\
\hline$(1-B) y$ & 2 & Yes & No & No & -2.96 & -8.45 & 36.91 & $\mathrm{I}(0,0)$ \\
\hline$(1-B) i^{*}$ & 0 & Yes & No & Yes & -4.94 & -6.31 & 51.09 & $\mathrm{I}(0,0)$ \\
\hline$(1-B) m$ & 0 & Yes & No & Yes & -4.17 & -5.12 & 21.63 & $\mathrm{I}(0,0)$ \\
\hline$(1-B) s^{2}$ & 0 & Yes & No & No & -4.88 & -4.76 & 27.44 & $\mathrm{I}(0,0)$ \\
\hline$(1-\mathrm{B}) b$ & 0 & No & No & No & -4.65 & -4.22 & 26.86 & $\mathrm{I}(0,0)$ \\
\hline$(1-B) b^{*}$ & 0 & Yes & No & No & -4.83 & -5.90 & 54.09 & $\mathrm{I}(0,0)$ \\
\hline$(1-B) F C$ & 0 & Yes & No & No & -3.08 & -4.37 & 23.36 & $\mathrm{I}(0,0)$ \\
\hline
\end{tabular}

Note: ${ }^{a}$ indicates significance at $5 \%$ level.

The multivariate LM test statistics specify the optimum lag period of the unrestricted VAR model, which is five quarters. Three central seasonal dummies and three intervention dummies are also included: D98 (Pakistan's nuclear test in 1998), D911 (the 9/11 terrorist attacks in 2001), and $D_{\text {afgwar }}$ (the US war against terror in Afghanistan after 9/11).

At the level, the MPBM variables have a linear trend and rise over time. As a result, the intercept term in the cointegration analysis is unrestricted. The results of Johansen's likelihood ratio test, trace and maximum eigenvalue statistics, after adjusting for small sample bias, are reported in Table 2. According to the trace statistic, MPBM contains only one cointegrating vector and found 
no evidence of long-run cointegration on the basis of maximum eigenvalue test statistic (Table 2). We will continue our analysis using the trace test, which is accurate in multiple cointegrating systems and robust in the case of error terms that are not normally distributed (Cheung and Lai, 1993 and Hubrich et al., 2001).

\section{Table 2: Cointegration Test Results of MPBM}

\begin{tabular}{|c|c|r|r|r|r|r|r|}
\hline \multicolumn{5}{|c|}{ Trace statistic } & \multicolumn{3}{c|}{ Maximum Eigenvalue statistic } \\
\hline Ho & $\mathrm{H}_{\mathrm{A}}$ & Chi- Square & $10 \% \mathrm{CV}$ & $\mathrm{Ho}$ & $\mathrm{H}_{\mathrm{A}}$ & Chi- Square & $10 \% \mathrm{CV}$ \\
\hline $\mathrm{r}=0$ & $\mathrm{r}>0$ & $155.67^{\mathrm{a}}$ & 153.63 & $\mathrm{r}=0$ & $\mathrm{r}=1$ & 48.45 & 49.29 \\
\hline $\mathrm{r} \leq 1$ & $\mathrm{r}>1$ & 107.22 & 120.36 & $\mathrm{r}=1$ & $\mathrm{r}=2$ & 35.63 & 43.29 \\
\hline $\mathrm{r} \leq 2$ & $\mathrm{r}>2$ & 71.59 & 91.11 & $\mathrm{r}=2$ & $\mathrm{r}=3$ & 23.40 & 37.28 \\
\hline $\mathrm{r} \leq 3$ & $\mathrm{r}>3$ & 48.19 & 65.82 & $\mathrm{r}=3$ & $\mathrm{r}=4$ & 20.96 & 31.24 \\
\hline $\mathrm{r} \leq 4$ & $\mathrm{r}>4$ & 27.23 & 44.49 & $\mathrm{r}=4$ & $\mathrm{r}=5$ & 11.57 & 25.12 \\
\hline $\mathrm{r} \leq 5$ & $\mathrm{r}>5$ & 15.66 & 27.07 & $\mathrm{r}=5$ & $\mathrm{r}=6$ & 10.11 & 18.89 \\
\hline $\mathrm{r} \leq 6$ & $\mathrm{r}>6$ & 5.55 & 13.43 & $\mathrm{r}=6$ & $\mathrm{r}=7$ & 4.85 & 12.30 \\
\hline $\mathrm{r} \leq 7$ & $\mathrm{r}>7$ & 0.70 & 2.71 & $\mathrm{r}=7$ & $\mathrm{r}=8$ & 0.70 & 2.71 \\
\hline
\end{tabular}

Note: ${ }^{a}$ that at the 10 percent level of significance the null hypothesis is rejected.

The long-run equation of ER under MPBM is estimated by normalizing the cointegrating vector on the log of ER in the following.

$$
s_{t}=2.64+0.06 m_{t}-0.05 b_{t}+0.02 b_{t}^{*}+0.001 i_{t}^{*}+0.95 s_{t}^{e}-0.21 y_{t}+0.04 F C_{t}
$$

The majority of the estimated parameter signs in equation (21) are consistent with MPBM's expectation. Equation (21) yields the following results:

- In the long run, a $1 \%$ rise in the domestic money supply is associated with a 0.06 percent depreciation in the nominal ER.

- According to a negative coefficient of national bonds on nominal ER, a one percent rise in national bond supply results in a $0.05 \%$ increase in national currency appreciation. It implies that in case of Pakistan, the substitution effect dominates the wealth effect which increases the demand for national bonds and results in appreciation of the national currency.

- A one percent rise in foreign bonds supply causes the nominal ER to depreciate by 0.02 percent.

- As the foreign interest rate has a positive coefficient on the ER, a rise in the foreign interest rate has a negative impact on Pakistan's nominal exchange rate. A $1 \%$ rise in the international interest rate causes a $0.001 \%$ depreciation of the national currency against the US dollar.

- A $1 \%$ rise in the expected exchange rate results in a 0.95 percent depreciation in the nominal ER.

- A rise in domestic production results in a 0.21 percent increase in the domestic currency.

- The financial crisis has significant influence on domestic exchange rate in case of Pakistan. The estimated parameter reveals that the foreign crisis depreciates the PKR by 0.04 percent. 
The residual deduced from equation (21) is now used to estimate the dynamic error correction MPBM that is equation (22).The estimation started by considering the drift term, three central seasonal dummies, intervention dummies $\left(\mathrm{D}_{98}, \mathrm{D}_{911}, \mathrm{D}_{\mathrm{afgwar}}\right)$, lag of error correction term and lag length of five for each of the first differenced variables ( $\Delta s, \Delta m, \Delta b, \Delta b^{*}, \Delta i^{*}, \Delta s^{e}, \Delta y$ and $\Delta F C$ ). By testing down and dropping insignificant terms, the following parsimonious dynamic MPBM is obtained ( $\mathrm{t}$ values are in parentheses):

$$
\Delta s_{t}=\begin{array}{cccccccc}
0.02 & +0.28 \Delta s_{t-1} & -0.02 \Delta b^{*}{ }_{t-1} & -0.12 \Delta m_{t-1} & -0.27 \Delta y_{t-2}-0.44 \Delta y_{t-4} & +0.06 \Delta F C_{t-2}-0.40 E C_{t-1} \\
(4.01) & (2.61) & (-1.54) & (-1.49) & (-1.72) & (-3.05) & (1.76) & -2.09
\end{array}
$$

$\operatorname{Adj} R^{2}=0.15 F_{(7,98)}=3.56 \operatorname{prob}(0.000)$

It is clear from the diagnostic test statistics that there is no evidence of autocorrelation $\left(\chi^{2}{ }_{(1)}=0.65\right.$ and $\left.\chi_{(4)}^{2}=2.21\right)$ and no $\mathrm{ARCH}\left(\chi_{(1)}^{2}=0.07\right.$ and $\left.\chi_{(4)}^{2}=1.03\right)$ at 5 percent level of significance. The CUSUM and CUSUMSQ (Brown et al.1975) tests are used to ensure that the parameter is stable. The plots of CUSUM and CUSUMSQ, shown in Figures 6 and 7, both remain within the $5 \%$ critical bound, suggesting that the dynamic MPBM is stable.

The estimated parameters of all the variables have the correct sign (except for the domestic money supply) are consistent with the theory. The dynamic MPBM (equation 22) shows that in the short run ER responds to change in international bonds supply, domestic money supply, and domestic real output and financial crisis. Apart from these variables, the exchange rate is explained itself by its lag value. A change in domestic output level in preceding quarters depreciates the national currency by 0.27 percent and 0.47 percent respectively. The estimated parameter of change in financial crisis has a depreciating effect on the exchange rate of Pakistan. It indicates that occurrence of financial crisis depreciates the exchange rate by 0.06 percent after two quarters. The estimated parameter of error correction term indicates that long-run equilibrium is stable. It shows that the exchange rate corrects its previous disequilibrium by 40 percent in each quarter. It takes about two-quarters to remove the 50\% disequilibrium from the exchange rate equilibrium path.

In Figure 8 we display the effect of financial crisis shock on exchange rate by estimating the impulse responses (over 20 months) to a one-standard-deviation positive financial crisis shock. In response to financial crisis shock the exchange rate rises permanently to higher level. Thus financial crisis leads to persistent depreciation of domestic currency of Pakistan. 
Figure 6: CUSUM of Recursive Residuals

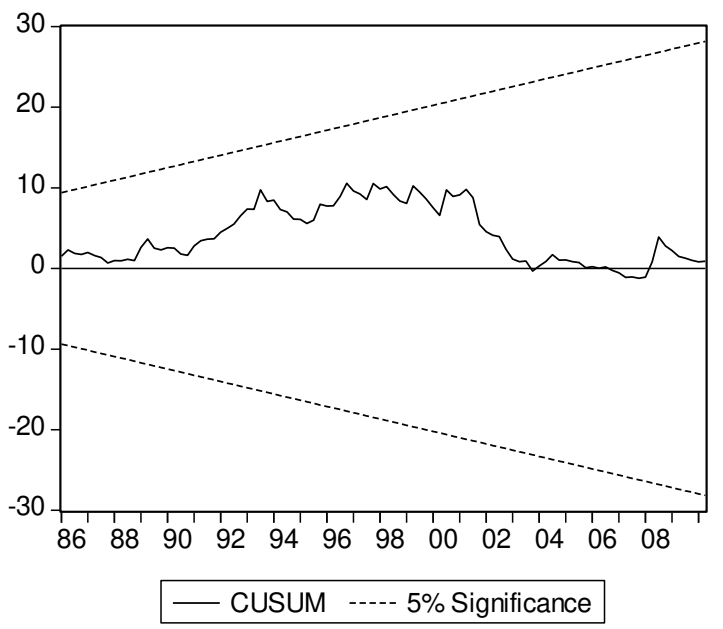

Figure 7: CUSUM Squares of Recursive Residuals

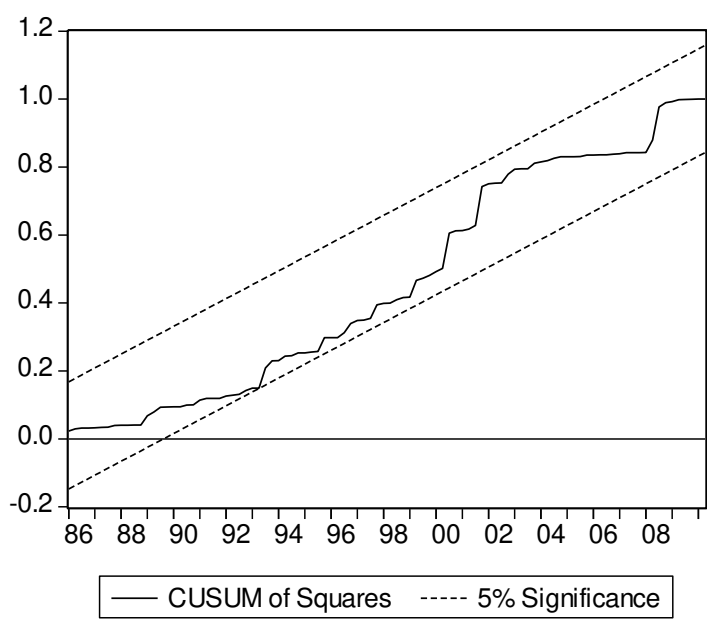

Figure 8: Impulse Response of Exchange Rate to FC shock

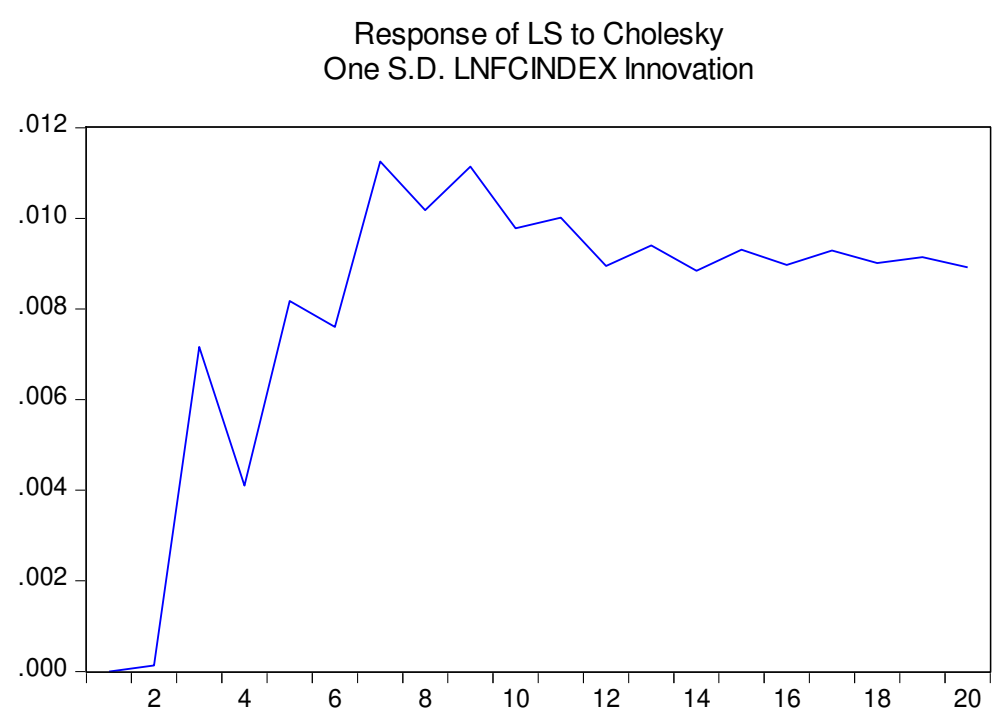

\section{Conclusion}

In this paper the influence of financial crisis on dynamics of exchange rate was captured by modifying the Portfolio balance model of Branson et al. (1985). The impact of financial crisis on exchange rate was examined under two cases. First case has considered a small domestic economy with no internal crisis. In this case the occurrence of financial crisis appreciates its currency by increasing the demand for national financial assets and decreasing the demand for international financial assets. Case two has considered the opposite economy which is experiencing a serious internal crisis at the time of external financial crisis. Hence, financial crisis originated in the foreign country affects the small country's growth by reducing its ability to attract the capital funds from abroad. The domestic investor then speculates that financial crisis further worsens the economic growth and weakens the domestic currency which further makes the domestic bond relatively riskier than foreign bond. This motivates them to change the structure of portfolio investment by 
shifting their money out of national bonds to international bonds and consequently it depreciates the domestic currency.

According to empirical analysis, financial crises depreciate the domestic currency both in the short and long run in Pakistan, a small open economy with a major internal crisis.

\section{Declaration}

Acknowledgements: The authors' thanks goes to Dr. Abdul Qayyum (Late) his guidance and suggestions prompted to revise the document and to make it valuable. The author remain responsible for any errors and weaknesses.

Authors' information (optional): Hafsa Hina <hafsahina@pide.org.pk, Office Telephone \# 092519248047> is Assistant Professor at, Pakistan Institute of Development Economics, Islamabad, Pakistan. Corresponding Author.

Muhammad Najeeb < m.najeeb@ hamdard.edu.pk> is Lecturer at Humdard University Islamabad> Authors' contribution: Hafsa Hina is responsible for the whole document regarding idea, theoretical development, empirical analysis and Muhammad Najeed help out only in the mathematical derivation of theoretical model.

A declaration of any potential competing interests; No there is not

Confirmation that all authors have approved the manuscript for submission; Yes

Confirmation that the content of the manuscript has not been published, or submitted for publication elsewhere; Not published Earlier

If you are submitting a manuscript to a particular special issue, please refer to its specific name in your covering letter; No, this study is not for particular issue

Availability of data and materials; The datasets generated and/or analyzed during the current study are available in the [International Financial Statistics (IFS), State Bank of Pakistan (SBP) Monthly Statistical Bulletin (various issues) and Treasury International Capital (TIC)] repository. Funding, Not Applicable

\section{References}

Allen, P.R., and Kenen, P.B. (1980), “Asset Markets, Exchange Rates, and Economic Integration”, Cambridge: Cambridge University Press.

Bilson,J.F.O. (1978), "The Monetary Approach to the Exchange Rate: Some Empirical Evidence”, IMF Staff Papers, Vol. 25 (March), pp. 48-75.

Branson, W. H. and Handerson, D. W. (1985), "The Specification and Influence of Assets Markets", In R. W. Jones, and P.B. Kene (Eds.), Handbook of International economic, Vol. 2, Amsterdam: Elsevier.

Branson, W. H. and Handerson, D. W. (1985), "The Specification and Influence of Assets Markets”, In R. W. Jones, and P.B. Kene (Eds.), Handbook of International economic, Vol. 2, Amsterdam: Elsevier.

Branson, W.H. (1979), "Exchange Rate Dynamics and Monetary Policy", Lindbeck, A. (ed.) (1979), Inflatiøn and Employment in Open Economies, Amsterdam: North Holland, pp. 189-224.

Branson, W.H., (1977), “Asset Markets and Relative Prices in Exchange Rate Determination”, SozialWissenschaftlicheAnnalen, 1. 
Brown, R.L., Durbin, J. and Evans, J.M. (1975),"Techniques for Testing the Constancy of Regression Relationships over Time", Journal of the Royal Statistical Society, Vol.37, pp.149-192.

Cheung, Y. -W. and Lai, K. S. (1993), "Finite-sample sizes of Johansen's likelihood ratio tests for cointegration", Oxford Bulletin of Economics and Statistics, Vol.55, pp. 313-328.

Cushman, D.O. (2007), "A Portfolio Balance Approach to the Canadian-U.S. Exchange Rate", Review of Financial Economics, Vol.16, pp.305-320.

Dornbusch, R. (1976), "The Theory of Flexible Exchange Rates and Macroeconomic Policy", Scandinavian Journal of Economics, Vol. 78 (2), pp. 255-75.

Fleming, J.M. (1962), "Domestic Financial Policies Under Fixed and Under Floating Exchange Rates”, I.N.F. Staff Papers, Vol. 9 (November), pp. 369-79.

Frenkel, J. A. and Johnson, H.G. (1978), "The Economics of Exchange Rate", Addison Wesley.

Haque, N, u., and Hina, H. (2020), "Five Currency Crisis of Pakistan", PIDE Knowledge Brief no. 7.

Hina, H. and Qayyum, A. (2019), "Effect of Financial Crisis on Sustainable Growth: Empirical Evidence from Pakistan", Journal of Asia Pacific Economy, Vol. 24(1), pp. 143-164.

Hina, H. and Qayyum, A. (2019), "Exchange Rate Determination and Out of Sample Forecasting: Cointegration Analysis", Skyline Business Journal, Vol. 11 (1), pp. 32-45

Hina., H. (2020), "Correction of Trade Deficit through Depreciation-A Misdirected Policy: An Empirical Evidence from Pakistan”, PIDE Working Paper no. 2020: 24.

Hubrich, K., Lütkepohl, H., and Saikkonen, P. (2001), "A review of systems cointegration tests", Econometric Reviews, Vol. 20, pp. 247-318.

Hylleburg, S., Engle, R.F., Granger, C.E.J. and Yoo, B.S. (1990), "Seasonal Integration and Cointegration", Journal of Econometrics, Vol. 44, pp. 215-28.

Isard, P. (1978) 'Exchange Rate Determination: A Survey of Popular Views and Recent Models', PrincetonStudies in International Finance, No. 42.

Johansen, S. and Juselius, K. (1992), "Testing Structural Hypothesis in a Multivariate CointegrationAnalysis of the PPP and UIP for UK", Journal of Econometrics, Vol. 53, pp. 211-44.

Kaminsky. G.L., and Reinhart, C.M. (1999), "The Twin Crises : The Causes of Banking and Balance-of-PaymentsProblems", American Economic Review, Vol89(3), pp. 473-500.

Kemal, A.R. and Arby, M. F. (2004), "Quarterisation of Annual GDP of Pakistan", Pakistan Institute of Development Economics, Islamabad, Statistical Papers Series No. 5, December.

Kouri, P.J.K. (1976), 'The Exchange Rate and the Balance of Payments in the Short Run and in the Long Run: A Monetary Approach", Scandinavian Journal of Economics, Vol. 78, No. 2, pp. 28-304.

Moosa, I. A. and Bhatti, R.H. (2009), "The Theory and Empirics of Exchange Rate", World Scientific.

Mundell, R.A. (1962), 'The Appropriate Use of Monetary and Fiscal Policy for Internal and External Stability", IMF Staff Papers, Vol. 9 (March), pp. 70-76.

Mussa M., 1976, 'The Exchange Rate, the Balance of Payments, and Monetary and Fiscal Policy under a Regime of Controlled Floating', Scandinavian Journal of Economics, Vol. 78, pp. 229-48.

Obstfeld, M. (1985), "Floating Exchange Rate: Expectations and Prospects”, Brooking Papers on Economic Activity, Vol.2, pp. 269-450. 
Pilbeam, K. (1998), International Finance, City University (London: Macmillan Business)

Tjahjawandita, A. Tito Dimas Pradono, T.D. and Rinaldi, R. (2009), "Spatial Contagion of Global Financial Crisis", Working Paper in Economics and Development Studies No. 200906, pp. 123-138.

Tjahjawandita, A. Tito Dimas Pradono, T.D. and Rinaldi, R. (2009), "Spatial Contagion of Global Financial Crisis", Working Paper in Economics and Development Studies No. 200906, pp. 123-138.

\section{Appendix}

Comparative static analysis on asset system is carried out to determine the relative effect of policy variables and financial crisis on exchange rate. Differentiating totally equations $1 \mathrm{a}-1 \mathrm{~d},{ }^{4}$ we get

$$
\begin{aligned}
& d M=W m_{Y} d Y+W m_{i} d i+W m_{i^{*}} d i^{*}+W m_{s^{e}} d s^{e}+W m_{s} d s+m d W \\
& d B=W b_{Y} d Y+W b_{i} d i+W b_{i^{*}} d i^{*}+W b_{s^{e}} d s^{e}+W b_{s} d s+W b_{F C} d F C+b d W \\
& B^{*} d S+S d B^{*}=W b_{Y}^{*} d Y+W b_{i}^{*} d i+W b_{i^{*}}^{*} d i^{*}+W b_{s^{e}}^{*} d s^{e}+W b_{s}^{*} d s+W b_{F C}^{*} d F C+b^{*} d W \\
& d W=d M+d B+B^{*} d s+s d B^{*}
\end{aligned}
$$

Substitute (6d) into (6a) and (6b) (note equation $6 \mathrm{~b}$ is neglected by Walras' law $^{5}$ )

$$
\begin{aligned}
& d M=W m_{Y} d Y+W m_{i} d i+W m_{i^{*}} d i^{*}+W m_{s^{e}} d s^{e}+W m_{s} d s+m\left(d M+d B+B^{*} d S+S d B^{*}\right) \\
& B^{*} d S+S d B^{*}=W b_{Y}^{*} d Y+W b_{i}^{*} d i+W b_{i^{*}}^{*} d i^{*}+W b_{s^{e}}^{*} d s^{e}+W b_{s}^{*} d s+W b_{F C}^{*} d F C+b^{*}\left(d M+d B+B^{*} d S+S d B^{*}\right)
\end{aligned}
$$

Rewrite the above equations (7) and (8) by taking endogenous variables (interest rate and exchange rate) on left hand side and exogenous variable (domestic money supply, domestic bond, foreign bond, foreign interest rate and expected rate of depreciation) on right hand side, because in short run they are given or fixed. We have

$$
W m_{i} d i+\left(W m_{s}+m B^{*}\right) d s=(1-m) d M-m d B-m s d B^{*}-W m_{i^{*}} d i^{*}-W m_{s^{e}} d s^{e}-W m_{Y} d Y
$$

\footnotetext{
${ }^{4}$ As given that $x=\frac{s^{e}}{s}-1, \frac{d x}{x}=\frac{d s^{e}}{s^{e}}-\frac{d s}{s}$. So if the proportion current exchange rate is greater than its long run equilibrium value $\bar{s}$, then the domestic currency will expected to appreciate (Because $x$ is negative).Substitute the value of $x=\frac{s^{e}}{s}-1$, in the argument of equation 1-3 and utilizing the above information, $M=m(\ldots, \bar{x}) W=m\left(\ldots, s^{e},+s^{+}\right) W \cdot s B^{*}=b^{*}\left(\ldots,{ }^{+}\right) W=b^{*}\left(\ldots, s^{e}, \bar{s}\right) W$ and $B=b(\ldots, \bar{x}) W=b\left(\ldots, s^{e}, s^{+}\right) W$. ${ }^{5}$ In n-market system, if there is a equilibrium in $\mathrm{n}-1$ markets implies equilibrium in the $\mathrm{n}^{\text {th }}$ market
} 
$W b_{i}^{*} d i-\left(B^{*}-b^{*} B^{*}-W b_{s}^{*}\right) d s=-b^{*} d M-b^{*} d B+\left(1-b^{*}\right) s d B^{*}-W b_{i}^{*} d i^{*}-W b_{Y}^{*} d Y-W b_{S^{E}}^{*} d s^{e}-W b_{F C}^{*} d F C$

In matrix form

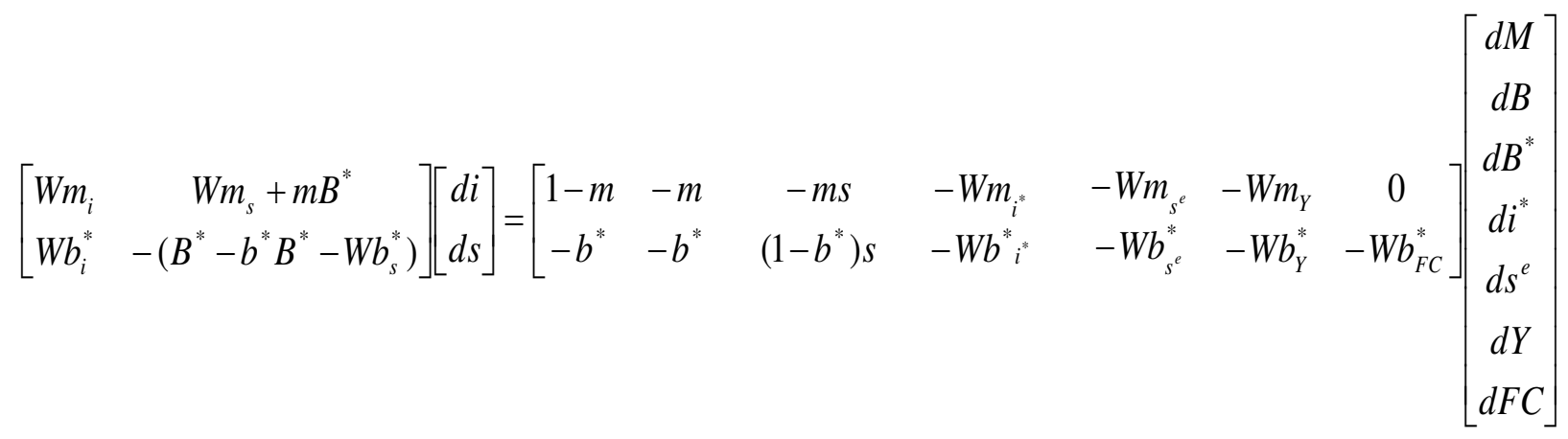

The sign of determinant of left hand side first matrix is positive because $m_{i}<0, b_{s}^{*}<0, b_{i}^{*}<0$, $m_{s}>0$ and $\left(1-b^{*}\right)>0$ i.e.

$$
\left|\begin{array}{cc}
W m_{i} & W m_{s}+m B^{*} \\
W b_{i}^{*} & -\left(B^{*}-b^{*} B^{*}-W b_{s}^{*}\right)
\end{array}\right|=-m_{i} W\left(B^{*}\left(1-b^{*}\right)-W b_{s}^{*}\right)-W b_{i}^{*}\left(W m_{s}+m B^{*}\right)>0
$$

